\title{
PROFESSIONAL HEALTH CARE PROGRAM AS A BASIC PERSONAL
} DEVELOPMENT RESOURCE

\section{КОМПЛЕКСНА ПРОГРАМА ЗБЕРЕЖЕННЯ ПРОФЕСІЙНОГО ЗДОРОВ'Я ЯК БАЗОВОГО РЕСУРСУ ОСОБИСТІСНОГО РОЗВИТКУ ПЕДАГОГА}

\author{
Olena Kosyhina \\ Олена Косигіна \\ Житомирський обласний інститут післядипломної педагогічної освіти \\ м. Житомир, Україна
}

Communal institution «Zhytomyr Regional Institute of Postgraduate Pedagogical Education» 1.

Анотація: Особистість учителя, як представника професії типу «людина - людина», у результаті тривалого виконання ним трудових функцій неминуче зазнає психологічних змін, які можуть негативно впливати на професійну діяльність у цілому. У зв’язку 3 цим зумовлюється пошук ефективних способів і технологій, що забезпечують педагогу оптимальні можливості збереження власної особистості і здоров’я.

Ключові слова: професійна деформація, педагог, профілактика, особистість.

Abstract. The personality of a teacher, as a representative of a profession of the type "man-man", as a result of the long-term performance of his labor functions, inevitably undergoes psychological changes that may adversely affect professional activity in general. In this connection, the search for effective methods and technologies that provide the teacher with optimal possibilities for preserving their own personality and health is determined. 
Key words: professional deformation, teacher, prevention, personality.

\section{Актуальність та постановка проблеми дослідження.}

Професійне здоров'я педагога $є$ необхідною умовою його активної життєдіяльності, самореалізації, розвитку творчого потенціалу. Воно позначається і на здоров'ї всіх інших учасників процесу міжособистісної взаємодії, на результатах всієї освітньої діяльності. Нездоровий педагог не зможе позитивно впливати на підвищення мотивації студентів/слухачів до якісного навчання та підвищення кваліфікаційного рівня, забезпечити необхідний рівень уваги, особистісний підхід, ситуацію успіху. Він не зможе займатися і розвитком здоров'язбережувальної компетентності у студентів/слухачів. Отже, прояви синдрому професійного згорання, педагогічних криз, деформації особистості педагога, неблагополуччя у психологічному стані, психічному здоров'ї, хроніфікація патологічного процесу на соматичному рівні безпосередньо впливають i на створення позитивного психологічного клімату у процесі освітньої міжособистісної взаємодії. Тому проблема збереження і зміцнення здоров'я викладача повинна бути однією із пріоритетних у сфері його життєвих і фахових інтересів. Психопрофілактичні програми, спрямовані на попередження професійних деформацій, мають набути широкого використання у контексті діяльності психологічних служб закладів вищої освіти.

Дотримуючись принципів організації освітнього процесу у системі післядипломної освіти, ми розробили профілактичні заходи і практичні поради, що здатні мінімізувати професійне вигорання педагогів, які проходять курси підвищення 
кваліфікації, та психопрофілактичні програми для викладачів, що працюють із дорослими людьми (студентами/ слухачами). У програму роботи з педагогами включені інтерактивні методи діяльності, спрямовані на профілактику подолання професійного вигорання, i, перш за все, - заходи, спрямовані на зняття дії стресора, зняття робочої напруги, підвищення професійної мотивації:

- професійне кураторство (надання індивідуальної і групової методичної професійної допомоги з певного фаху);

• емоційна підтримка (індивідуальні консультації, складання плану особистісного розвитку, планування часу поза роботою, що включає заняття спортом, правильне харчування, відпочинок та розваги, хобі, стосунки з родичами та друзями);

- управління стресом/запобігання стресу (техніки релаксації, арт-терапевтичні заняття, тренінгові заняття, балінтовські групи, а також проведення виїзних семінарів та занять (за запитом), присвячених розвитку навичок управління часом, побудові позитивних стосунків у команді).

3 метою спрямованої профілактики емоційного виснаження педагогам рекомендовано:

• навчитися розраховувати й обдумано розподіляти своє навантаження;

• забезпечувати відпочинок перед початком роботи;

• планувати час за межами професійної діяльності;

• вчитися переключатися з одного виду діяльності на інший.

Спираючись на основні теоретичні підходи до вивчення синдрому вигорання, нами розроблені рекомендації із запобігання професійного стресу і профілактики професійного вигорання, які 
представляють собою сукупність превентивних заходів, орієнтованих на зниження вірогідності розвитку передумов i проявів професійного стресу та синдрому вигорання. Необхідно також скласти індивідуальну програму для підтримання кожним педагогом власного фізичного й психоемоційного стану у тонусі. Впровадження інтерактивної роботи із запобігання професійного стресу та профілактики професійного вигорання у системі післядипломної освіти сприятиме подальшому особистісному розвитку, який $€$ передумовою розвитку професійних компетентностей педагога.

Професійна деформація педагогічних працівників являє собою процес поступового формування негативних змін у сталій структурі діяльності й особистості, що позначається на продуктивності праці, якості взаємодії з іншими учасниками освітнього процесу [5], відчутті комфорту, стані суб'єктивної задоволеності власним життям, почутті психологічної безпеки в умовах співпраці всіх учасників освітньої взаємодії.

На думку Грановської Р. М., професійні деформації проявляються через стереотипні дії. Слід зазначити, що на початку професійної діяльності розвиток стереотипних дій корисний, тому що вони сприяють покращенню первинного адаптаційного періоду. Але 3 часом стереотипії починають гальмувати професійний розвиток педагога, так як набувають домінуючий характер у діяльності викладача. Сприйняття ситуацій стає спрощеним, виникає самоупевненість в непогрішності засвоєних педагогічних методів i власних можливостей, що призводить до звуження обсягу професійного мислення, експлуатації одноманітних поведінкових алгоритмів. 
Здійснений нами теоретичний аналіз проблеми розвитку професійних деформацій у педагогів та їх специфіки в умовах вищої школи, результати експериментального дослідження надають можливість стверджувати, що запропоновані науковцями педагогічні умови, визначений інструментарій та комплексна програма профілактичної роботи можуть у подальшому бути використані у практичній роботі психологічної служби університетів, Центрів практичної психології Інститутів післядипломної освіти, у професійній діяльності викладачів вищої школи та системи післядипломної освіти.

Проблема попередження професійних деформацій привертала постійну увагу науковців і практиків: психологів, лікарів, філософів. У контексті нашого дослідження важливе значення мають положення та висновки вітчизняних і зарубіжних науковців щодо виявлення головних чинників, що сприяють розвитку професійних деформацій у педагогів (об'єктивних, суб'єктивних та об'єктивно- суб'єктивних).

Сучасні науковці Агапов В.С., Безносов В.Г., Борисова М. В., Желагіна Т. А., Кузьміна Н. В., Мітіна Л. М., Сінягіна Н. Ю. виділяють наступні типи професійної деформації особистості педагога:

а) загальнопедагогічні деформаиї (характеризуються типовими змінами особистості у всіх осіб, що займаються педагогічною діяльністю);

б) типологічні деформації (викликані злиттям особистісних особливостей з відповідними структурами функцій педагогічної діяльності у поведінкові комплекси); 
в) спецฺифічні деформащиї особистості педагога (обумовлені специфікою викладання навчальних дисциплін);

г) індивідуальні деформації (визначаються змінами, що відбуваються з підструктурами особистості і зовні не пов’язані 3 процесом педагогічної діяльності; коли відбувається розвиток якостей, що не мають безпосереднього відношення до педагогічної професіi).

До основних суб'єктивних ознак сприятливого для якісної міжособистісної взаємодії соціально-психологічного клімату у закладі освіти належать: можливість для членів колективу вільно висловлювати власні думки під час обговорення питань; відсутність тиску керівника на підлеглих і визнання за ними права приймати відповідальні для колективу рішення; достатня інформованість членів колективу про завдання та стан справ під час їхнього виконання; задоволеність належністю до колективу; прийняття на себе відповідальності за стан справ у колективі кожним його членом.

Як свідчить практика, реальне життя будь-якої організації це комплексне поєднання службових, організаційноуправлінських та міжособистісних стосунків. Члени педагогічного колективу, з притаманними їм психологічними особливостями, особистими пристрастями та інтересами, власною мотивацією впливають на якість та характер загального психологічного клімату. Через те виникає необхідність наукового аналізу психологічної атмосфери, 3 метою своєчасної профілактики та корекції негативних явищ у колективі педагогів. Серед таких явищ досить активно може розповсюджуватися i мобінг [4]. Нажаль, випадки мобінгу здатні поставити під загрозу 
виконання професійних завдань, що стоять перед конкретним педагогічним колективом, негативно вплинути на психосоматичне здоров'я його членів.

Отже, проведення ефективної роботи щодо вивчення мобінгу у педагогічному колективі потребує здійснення глибинного аналізу цього соціально-психологічного явища. Цілком очевидним $є$ те, що превентивний зміст діяльності керівника закладу вищої освіти вимагає відповідних знань, умінь та навичок. Глибинне вивчення ситуації конфлікту дозволяє керівникові отримати уточнення цілей та завдань щодо оздоровлення психологічного клімату, з'ясування причин та обставин виникнення мобінгу, здійснити аналіз результатів вивчення мобінгу, підбір оптимальних варіантів подолання мобінгу серед підлеглих. Результати нашого вивчення цієї проблеми свідчать про те, що основними завданнями керівника при діагностицุi мобінгу серед підлеглих мають бути:

1. Вивчення соціально-психологічного клімату конкретної групи.

2. Виявлення ініціаторів мобінгу.

3. Виявлення жертви мобінгу.

4. Виявлення пасивних (вимушених) учасників мобінгу.

5. Виявлення психологічних, соціально-економічних передумов виникнення мобінгу у підрозділі.

6. Вивчення наслідків мобінгу для його ініціатора та жертви.

Практика свідчить, що керівник підрозділу має можливість отримати інформацію про мобінг різними шляхами: 
- до нього може звернутися безпосередньо жертва мобінгу;

- його можуть проінформувати молодші керівники або інші підлеглі;

- його можуть проінформувати родичі жертви мобінгу;

- він може бути свідком мобінгу особисто.

Отримавши необхідну інформацію про зміст процесу мобінгу, керівник повинен без зволікань реалізувати ряд заходів щодо його подолання. 3 цією метою нами пропонується програма психологічної діагностики та подолання керівником закладу вищої освіти випадків мобінгу серед викладачів. Необхідно застосувати системний підхід, при якому діяльність керівника підрозділу має бути присвячена досягненню конкретної мети виявленню та подоланню процесу мобінгу серед підлеглих. Зважаючи на аналіз наукових джерел [2; 5], досягнення такої мети тісно пов’ язано з вирішенням низки завдань, зокрема:

-вивчення морально-психологічного клімату $\mathrm{y}$ педагогічному колективі;

-діагностика міжособистісних стосунків між членами підрозділу;

-виявлення суб’єктів та об’єктів мобінгу та стратегій їх поведінки;

-подолання явища мобінгу;

-зміцнення почуття відповідальності членів колективу за морально-психологічний клімат у підрозділі.

При розробці програми, ми враховували те, що вона повинна відображати всі аспекти роботи щодо виявлення та подолання мобінгу у колективі. Отже програма має відображати 
сукупність методів (способів) діагностики та подолання керівником мобінгу серед підлеглих. Наше дослідження свідчить про те, що превентивна функція в управлінській діяльності керівника підрозділу реалізується через постійний збір, аналіз фактів деструктивної взаємодії, об'єктивне оцінювання морально-психологічного клімату підрозділів та своєчасне проведення заходів щодо усунення проблем у міжособистісних стосунках науково-педагогічних працівників; здійснення комплексної психологічної діагностики та корекції функціональних порушень у психологічному здоров’ї членів колективу.

На психологічному кліматі колективу у закладі вищої освіти позначаються також взаємини співробітників із тими, на кого вони самі впливають за характером своїх професійних обов'язків. Задоволеність педагогів стосунками зі студентами/слухачами набуває великого значення у зв'язку із демократизацією та гуманізацією освітнього процесу. Постійна якісна взаємодія «викладач -студент» - одна 3 найважливіших умов у роботі, базова мотивація до вдосконалення педагогічної майстерності, творчості. А позитивні стосунки зі студентами можуть стати (на певному етапі) компенсуючим фактором, який допомагає педагогу пережити такі негативні обставини, як складні взаємини з колегами та керівництвом, недостатня оплата праці, несприятливі життєві обставини. Професійна психологічна служба в освітньому закладі має стати центральним структурним підрозділом, що сприятиме збереженню й зміцненню соматичного, психічного здоров'я кожного члена колективу, профілактиці формування у них синдрома 
професійного вигорання, психологічному супроводу педагога у ситуації життєвої чи професійної кризи, покращенню соціальнопсихологічного клімату у педагогічному колективі закладу вищої освіти.

Серед рекомендаціiй працівникам психологічної служби щодо покращення мікроклімату можна зазначити наступні:

- Проводити систематично соціометричне чи референтометричне дослідження для аналізу стану мікроклімату колективу з метою виявлення «вогнища» проблеми.

- Проводити діагностику синдрому професійного вигорання та інформувати педагогів шодо прийомів уникнення емоційного виснаження.

• Надавати психологічну допомогу членам колективу (за запитом) щодо саморегуляції психічних процесів шляхом аутогенного тренування, індивідуальної та групової психокорекції.

- Проводити тренінгові заняття з особистісного розвитку.

- Організувати цикл тренінгових занять із розвитку психологічної культури педагогів.

- На початку навчального року проводити заняття 3 психологічної адаптації (з метою прискорення темпу включення педагогів та студентів в освітній процес).

- Виявляти співробітників, які впливають на погіршення мікроклімату та індивідуально працювати з ними над розвитком корпоративної культури, психологічної згуртованості у колективі, здатності до самоуправління, підвищення рівня здоров’язбережувальної компетентності. 
- Організувати проведення інтегрованих та бінарних заходів, семінарів, тренінгів, що сприятиме підвищенню ефективності взаємодії між членами педагогічного колективу.

Зазначимо, що усвідомлення педагогом дезадаптаційних тенденцій у професійній діяльності $\epsilon$ важливим напрямом превентивної роботи у післядипломній педагогічній освіті, що передбачає пошук способів забезпечення збереження цілісності особистості.

Пропонуємо для отримання педагогом оцінки рівня перевантаження, конкретних практичних рекомендацій щодо здійснення самозмін у професійній діяльності використовувати можливості сучасних цифрових технологій, зокрема, додатки тайм-менеджери (органайзери) для продуктивнішого управління власним часом. Серед них - Google Календар. Його функціонал дозволяє раціонально спланувати розпорядок дня пегагога, знайти час для особистого життя i закцентувати увагу на своєчасному виконанні важливої роботи (рис. 1). Календар сповіщає про необхідність здійснення конкретно запланованих дій, за потребою у ньому налаштовується повторюваність.

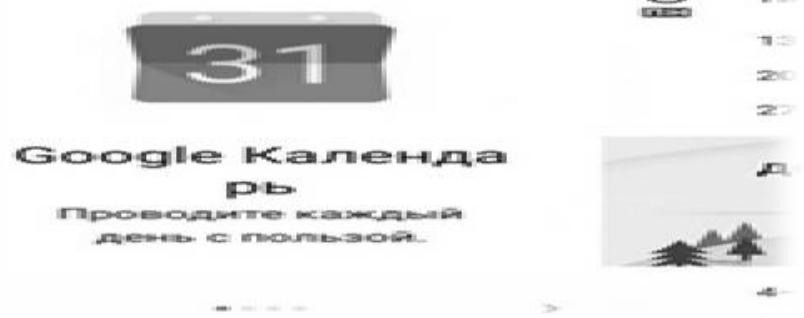

Рис. 1. Інтерфейс програми Google Календар

Водночас, можна створювати нагадування про події чи заходи професійного життя, де вказується місце проведення 
заходу, точний час; педагог має можливість вибрати характер оповіщення (SMS, e-mail). Планування допоможе оптимізувати власне життя для більшої продуктивності і профілактики стресів.

Серед базових рекомендацій педагогічним працівникам необхідність максимально раціоналізувати виконання професійних дій, що сприятиме підтримці правильного життєвопрофесійного балансу, особистісному успіху.

Таким чином, необхідним для успішного професійного розвитку педагога вищої школи критерієм $\epsilon$ професійне та особистісне самозбереження, постійна рефлексія власного «Я», самоаналіз професійної діяльності, перманентне професійне та особистісне самоудосконалення й усвідомлення того, що в певні періоди професійної кар'єри він потребує допомоги фахівцяпсихолога, основним завданням якого і є психологічний супровід, фасилітація успішної професіоналізації особистості.

Висновки та перспективи подальшого дослідження.У психологічному супроводі педагога щодо збереження і зміцнення його психосоматичного здоров'я, сприяння особистісному зростанню, для практичного психолога існує велике поле діяльності: просвітницька, діагностична і психокорекційна робота з метою:

-підвищення грамотності науково-педагогічних працівників iз питань збереження їхнього професійного здоров'я;

-попередження професійних деформацій (як загальнопедагогічних, так і типологічних);

-допомога у формуванні психологічного захисту від стресу, при потребі - у подоланні наслідків стресогенних, кризових та надзвичайних ситуацій, усуненні синдрому емоційного згорання; 
-профілактика педагогічних криз і допомога в усуненні їх наслідків;

-допомога в усуненні невротичних, психотичних i психосоматичних розладів та залучення при необхідності відповідних вузьких спеціалістів-лікарів (з метою недопущення хроніфікації патологічних процесів);

-превентивна робота зі створення сприятливого психологічного клімату у педагогічному колективі, у співпраці 3 адміністрацією освітнього закладу, 3 метою створення психологічно безпечного освітнього середовища.

Психолог, що працює у закладі вищої освіти, повинен бути теоретично обізнаний щодо проявів дезадаптаційних тенденцій у діяльності педагогів, уміти розробляти комплексні психопрофілактичні програми для збереження професійного здоров’я педагогів, гармонізації їх внутрішнього світу. В арсеналі практичного психолога мають бути валідні та надійні методики для оцінки загального психічного стану, самопочуття особистості, для виявлення відхилень у психоемоційній сфері, схильності до емоційного згорання, ступеня ефективності адаптаційних механізмів у ситуації стресу. Для реалізації визначених завдань фахівець може використовувати різноманітні методи роботи: як індивідуальні, так і групові бесіди та консультації, семінари за тематикою профілактики синдрому емоційного вигорання, психологічні тренінги, психотехнічні ігри; має володіти технологіями зняття психоемоційної напруги, методами психічної саморегуляції для здійснення якісного психологічного супроводу викладачів в умовах специфічної міжособистісної взаємодії у закладах вищої та післядипломної освіти. 
Участь у тренінгах, виїзних семінарах, курсах підвищення кваліфікації, а відповідно і перехід на нову кваліфікаційну категорію або посаду (підвищення почуття відповідальності, новизна роботи) стають значущою мотивацією для подолання почуття повсякденності та емоційного вихолощення. Періодична зміна характеру діяльності, використання можливостей інформаційно-комунікаційних технологій, оновлення програми навчальної дисципліни, зміна місця проживання і роботи можуть стати ефективним засобом профілактики професійних деформацій у викладачів вищої школи. Важливого значення набуває і комплексна діяльність всієї команди професіоналів зі створення сприятливого психологічного клімату у педагогічному колективі, у тісній співпраці з адміністрацією освітнього закладу, 3 метою створення безпечного освітнього середовища, в якому реалізуються цілі та завдання всіх учасників міжособистісної взаємодії.

\section{Список використаних джерел}

1. Алберти, P. Самоутверждающее поведение. Распрямись! Выскажись! Возрази! / Р. Алберти, М. Эммонс ; пер. с англ. М. В. Горшкова. - СПб.: «Академический проект», 1998. 190 c. c. 17.

2. Андреева Г. М. Социальная психология: учебник для высших учебных заведений. М.: Аспект Пресс, 1997. 376 с.

3. Басенко В. П., Жуков Б. М., Романов А. А. Организационное поведение: современные аспекты трудовых отношений. Учебное пособие. Издательство "Академия Естествознания", М.: 2012. - 384 с. 
4. Басова А. Г. Формирование эмпатии [Текст] / А. Г. Басова // Молодой ученый. — 2013. — №5. — С. 631-633.

5. Берн Э. Трансактный анализ и психотерапия. СПб., 1992.- 224c.

6. Беспалов Ю. Ассертивность - качество Лидера, или, как быть твердым в целях, но гибким в средствах [Электронный pecypc] [Режим доступа]: http://nlp.by/about-nlp/nlp-styi-ipublikacii/215-assertive-kacestvo-lidera.

7. Степанов О. М. Психологічна енциклопедія /О. М. Степанов. - К.: "Академвидав", 2006. - 32 с.

8. Столин В. В. Самосознание личности. - М.: Изд-во МГУ, 1983. - $286 \mathrm{c.}$

9. Стрелкова, Л. П. Психологические особенности развития эмпатии у дошкольников: автореф. дис. ... канд. психол. наук: 19.00.07 / Л. П. Стрелкова; АПН ССС, НИИ дошк. воспитания. - М., 1987. - 24 с.

10. Х Харламенкова, Н. Е. Разработка валидной процедуры оценки самоутверждения личности / Н. Е. Харламенкова, Е. П. Никитина // Психологический журнал. - 2000. - Т. 21. - № 6. - C. 67-76.

11. Хохлова, Е. В. Конструктивная агрессивность в формировании навыков ассертивного поведения студентов вуза: автореф. дисс. на соискание учен. Степени канд. психол. наук : спец. 19.00.07 “Педагогическая и возрастная психология" /Е. В. Хохлова. - Нижний Новгород, 2008. - 26 с.

12. Шамиева, В. А. Ассертивность в структуре личности субъекта адаптации: автореф. дисс. на соискание учен. степени канд. психол. наук: спец. 19.00.01 “Общая психология, история 
психологии" / В. А. Шамиева. - Хабаровск, 2009. - 207 с.

13. Шамиева, В. А. Ассертивность в структуре личности субъекта адаптации / В. А. Шамиева, К. И. Воробьева // Социально-гуманитарные науки на Дальнем Востоке: сборник статей. - Хабаровск : Изд-во ДВГУПС, 2009. - № 4. - С. 79-83.

\section{REFERENCES (TRANSLATED \& TRANSLITERATED)}

1. Alberti, R. Samoutverzhdayushhee povedenie. Raspryamis'! Vy`skazhis'! Vozrazi! [Self-affirming behavior. Straighten up! Speak out! Object!] / R. Alberti, M. E`mmons ; per. s angl. M. V. Gorshkova. - $\mathrm{SPb} .:$ «Akademicheskij proekt», 1998. - 190 s. s.17. [In Russian]

2. Andreeva G. M. Soczial ’naya psikhologiya: uchebnik dlya vy`sshikh uchebny`kh zavedenij [Social Psychology: A Textbook for Higher Education]. M.: Aspekt Press, 1997. 376 s. [In Russian]

3. Basenko V.P., Zhukov B.M. , Romanov A.A. Organizaczionnoe povedenie: sovremenny`e aspekty` trudovy`kh otnoshenij [Organizational behavior: modern aspects of labor relations. Tutorial]. Uchebnoe posobie. Izdatel`stvo "Akademiya Estestvoznaniya", M.: 2012. - 384 s. [In Russian]

4. Basova A. G. Formirovanie e'mpatii [Empathy Formation] / A. G. Basova // Molodoj ucheny`j. 2013. \#5. S. 631-633. [In Russian]

5. Bern E`. Transaktny`j analiz i psikhoterapiya [Transactional Analysis and Psychotherapy]. SPb., 1992.- 224s. [In Russian]

6. Bespalov Yu. Assertivnost - kachestvo Lidera, ili, kak by' $t$ ' tverdy' $m \mathrm{v}$ czelyakh, no gibkim $\mathrm{v}$ sredstvakh [Assertiveness is the quality of the Leader, or how to be firm in goals, but flexible in 
means] [E`lektronny`j resurs] [Rezhim dostupa]: http://nlp.by/aboutnlp/nlp-styi-i-publikacii/215-assertive-kacestvo-lidera. [In Russian]

7. Stepanov O.M. Psikhologi'chna encziklopedi'ya [Psychological Encyclopedia] /O.M. Stepanov. - K.: "Akademvidav", 2006. - 32 s. [In Russian]

8. Stolin V. V. Samosoznanie lichnosti [Self identity of the personality]. - M.: Izd-vo MGU, 1983. - 286 s. [In Russian]

9. Strelkova, L.P. Psikhologicheskie osobennosti razvitiya e'mpatii u doshkol'nikov [Psychological features of the development of empathy in preschool children]: avtoref. dis. ... kand. psikhol. nauk: 19.00.07 / L.P. Strelkova; APN SSSR, NII doshk. vospitaniya. M., 1987. - 24 s. [In Russian]

10. Kharlamenkova, N. E. Razrabotka validnoj proczedury oczenki samoutverzhdeniya lichnosti [Development of a valid procedure for assessing self-identity] / N. E. Kharlamenkova, E. P. Nikitina // Psikhologicheskij zhurnal. - 2000. - T. 21. - \# 6. - S. 6776. [In Russian]

11. Khokhlova, E. V. Konstruktivnaya agressivnost' $\mathrm{v}$ formirovanii navy`kov assertivnogo povedeniya studentov vuza [Constructive aggressiveness in the formation of assertive behavior skills of university students] : avtoref. diss. na soiskanie uchen. Stepeni kand. psikhol. nauk : specz. 19.00.07 "Pedagogicheskaya i vozrastnaya psikhologiya" /E. V. Khokhlova. - Nizhnij Novgorod, 2008. - 26 s. [In Russian]

12. Shamieva, V. A. Assertivnost' v strukture lichnosti sub'ekta adaptaczii [Assertiveness in the personality structure of the subject of adaptation]: avtoref. diss. na soiskanie uchen. stepeni kand. psikhol. nauk: specz. 19.00.01 "Obshhaya psikhologiya, istoriya 
psikhologii” / V. A. Shamieva. - Khabarovsk, 2009. - 207 s. [In Russian]

13. Shamieva, V. A. Assertivnost' v strukture lichnosti sub'ekta adaptaczii /V. A. Shamieva, K. I. Vorob'eva [Assertiveness in the personality structure of the subject of adaptation] // Soczial'nogumanitarny`e nauki na Dal'nem Vostoke: sbornik statej. Khabarovsk: Izd-vo DVGUPS, 2009. - \# 4. - S. 79-83. [In Russian 